
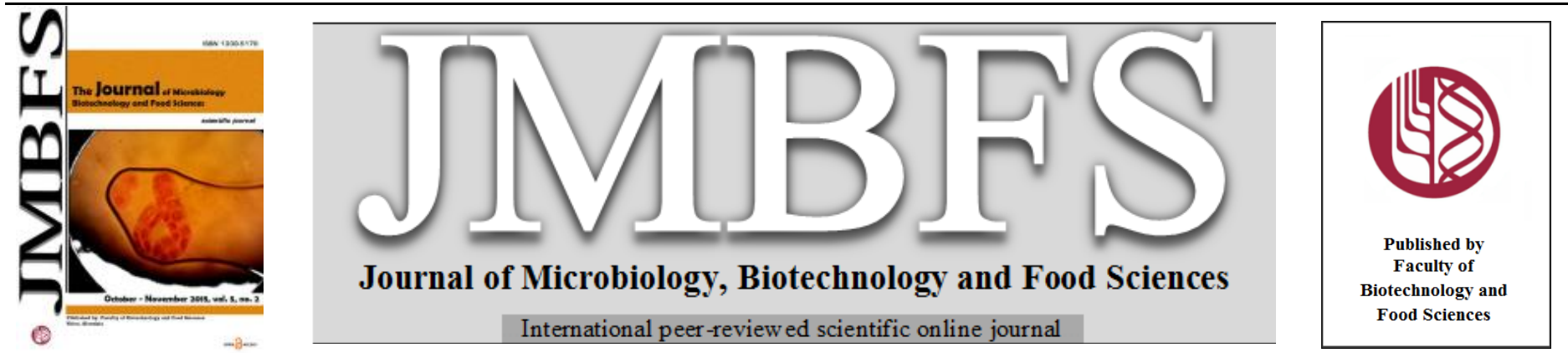

\title{
CHARACTERISATION OF CASSAVA BAGASSE IN DIFFERENT GRANULOMETRIES FROM TWO STARCH PROCESSING PLANTS
}

\author{
Érica Caroline da Silva ${ }^{l}$, Marney Pascoli Cereda ${ }^{2}$, Tiago André Denck Colman ${ }^{*}$, Ivo Mottin Demiate $^{l}$, Egon Schnitzler
}

Address(es):

${ }^{1}$ Ponta Grossa State University - Av. Carlos Cavalcanti, 4748 - Ponta Grossa PR, 84030-900 - Brazil - Tel.: +55 4232203093.

${ }^{2}$ Dom Bosco Catholic University - Avenida Tamandaré, s/n - Lagoa da Cruz, Campo Grande MS - 79117-900 - Brazil.

*Corresponding author: tiago.colman@outlook.com

doi: 10.15414/jmbfs.2015.5.2.99-102

\section{ARTICLE INFO}

Received 20. 8. 2014

Revised 26. 9. 2014

Accepted 11. 6. 2015

Published 1. 10. 2015

Regular article

OPEN 2 ACCESS

\begin{abstract}
Cassava is an agricultural crop that occupies an important place in the diet of people of many countries in tropical and sub-tropical regions. Cassava bagasse is a by-product from industrial processing that is generated in great quantities and it can exhibit about 40-50\% of starch in its composition, in dry basis. Two samples, one moist (sample A) and another dry (sample B), were supplied by two cassava starch industries. The samples were analysed by physicochemical, thermoanalytical (TG, DTA, DSC), rheological (RVA) and microstructural methods (NC-AFM) that demonstrated that the temperature of the industrial drying (around $150{ }^{\circ} \mathrm{C}$ ) was not very well controlled, reaching higher temperatures, reaching decomposition of organic matter condition causing changes (please specify) and browning. Although it was milled, sieved and contained $41.31( \pm 0.43) \%$ of starch, sample B did not present gelatinisation or paste properties. Sample A, with $47.75( \pm 0.21) \%$ of starch, dried carefully in a laboratory oven with forced air circulation at $45^{\circ} \mathrm{C}$ for 24 hours showed gelatinisation enthalpy $\left(\Delta \mathrm{H}_{\mathrm{gel}}\right)$ and viscosity with values directly proportional to the granulometry.
\end{abstract}

Keywords: Cassava bagasse, thermal analysis, viscosity, atomic force microscopy

\section{INTRODUCTION}

Cassava (Manihot esculenta Crantz) is considered to be an important source of food and dietary calories for a large part of the population in tropical and subtropical countries in Latin America, Africa and Asia. It is a rich source of starch and also contains fibres, proteins, lipids, sugars and other substances (Cereda, 2001).

Cassava bagasse is a fibrous material resulting as a by-product of the cassava starch processing industry. It is an agro-industrial residue that can offer economic opportunities as an alternative substrate for the fermentation industry. This residue contains starch, about $50 \%$ on a dry weight basis, a considerable quantity of natural fibre and low contents of ash, protein and lipids (Carta, 1999; Matsui et al., 2003; Pandey et al., 2000a; Texeira et al., 2005).

Starch and cellulose are natural polysaccharides and they are the most abundant renewable resources available to mankind. They are both glucose polymers that are photosynthesised by solar energy. Plants have starch as a reserve and cellulose as the structural basis of the plant cell wall. These polymers also constitute a major energy source in human and animal diets. They are widely used as raw material in numerous industrial applications such as textiles, food, paper, paint, petroleum, pharmaceutical, bioprocess, and others (Matsui et al. 2003; Pandey et al., 2000a; Pandey et al., 2000b; Richardson et al., 2003; Sivaramakrishnan, et al., 2007; Sun et al., 2013)

Starch is the main source of carbohydrates in the human diet due to its abundance in nature. Starch granules are made up of glucose polymers, named amylose and amylopectin, and they are found inside vegetable cells, from where they are extracted for industrial applications by the food, textile, pulp and paper industries among many. Amylose is a mostly linear chain and typically consists up to 3000 anhydroglucose units (AGU) primarily interconnected by $\alpha-(1 \rightarrow 4)$ glycosidic linkages; it is also reported that it contains a few branched chains (Vilaplana $e$ al., 2012). Amylopectin is a highly branched polysaccharide consisting of $\alpha$ $(1 \rightarrow 4)$ linked glucose with $\alpha-(1 \rightarrow 6)$ linkages at the branch points (Beninca, et al., 2012; Costa et al., 2011; Leivas et al., 2012; Matsuguma et al., 2009; Vilaplana et al., 2012).

Cellulose is a uniform, linear, glucose polymer and is the most abundant of all naturally occurring substances. Polymers constitute approximately one third of all vegetable matter as they are the principal structural cell wall component of all major plants, such as trees, annual plants, mosses, seaweeds and cotton, in which cellulose occurs in varying amounts (Richardson et al., 2003; Abdul-Khalil et al., 2012).

According to the literature (Pandey et al., 2000), the industrial processing of cassava is carried out mainly to isolate starch, which generates a great quantity of solid residue that contains $30-50 \%$ of starch in dry.

Whenever a material undergoes a change in physical state, is transformed from one crystalline form to another, or it reacts chemically, heat is either absorbed or liberated as energy (endothermic or exothermic processes, respectively)(Cereda, 2001; Lacerda et al., 2008a). Many of such processes can be initiated simply by raising the temperature of the material. Differential thermal analysis (DTA) and differential scanning calorimetry (DSC) techniques have proven most useful in providing basic information on starch gelatinisation and retrogradation (Lacerda et al., 2008b).

Thermogravimetry (TG) is a technique in which the change in sample mass $(\Delta \mathrm{m}$, mass-loss or gain) is determined as a function of temperature and/or time. DTA is a technique that measures the difference in temperature between the sample and the reference. DSC is a technique whereby the difference in energy input into a substance and a reference material (sample and reference) is measured as a function of temperature, while both materials are subjected to programmed heating or cooling (Wendlandt, 1986).

For the last few decades, DSC has been widely used to study the gelatinisation of starch, a physical transformation that occurs when starch-water slurry is submitted to a heating process. Some applications of these methods can be found in several published texts (Alberton et al., 2014; Colman et al., 2012; Cordoba et al., 2013; Zhang, X. et al., 2013; Pongsawatmanit et al., 2007; Beninca, et al., 2012; Costa et al., 2011; Fukuoka et al., 2002; Kiseleva et al., 2005; Lacerda et al., 2009; Lacerda et al., 2008a; Lacerda et al., 2008b; Leivas et al., 2012; Matsuguma et al., 2009).

In this present study, cassava bagasse samples were obtained from two starch processing plants with different moisture contents; one industrially dried and another moist. Selected physicochemical, thermoanalytical, rheological and microscopic methods were employed for their characterisation.

\section{MATERIAL AND METHODS}

Samples of cassava bagasse were obtained directly as a by-product from two starch industries (A) and (B) located in the northwest region of Paraná State and 
the south of São Paulo State, Brazil. The first sample (A) was obtained with high moisture content $(80.5 \%)$ and the sample (B) was obtained with low moisture content $(8.2 \%)$; this last sample had brownish colouration due to the industria drying process that exceeded $150^{\circ} \mathrm{C}$. The samples were milled and sieved at 20 150 and 270 mesh $(840,105$ and $53 \mu \mathrm{m}$, respectively).

Physicochemical analysis: The moisture, protein, reducing sugars, ash and $\mathrm{pH}$ contents were determined according to protocols of the Association of Official Analytical Chemists (AOAC, 2010) and of Adolfo Lutz Institute, (IAL, 2008).

Simultaneous thermogravimetry and differential thermal analysis (TG-DTA) The samples were heated from $30{ }^{\circ} \mathrm{C}$ to $600^{\circ} \mathrm{C}$ using open alumina crucibles with approximately $6.0 \mathrm{mg}$ of sample under a synthetic air flow of $100 \mathrm{~mL} \mathrm{~min}^{-1}$ at a heating rate of $10{ }^{\circ} \mathrm{C} \mathrm{min}^{-1}$. The samples were analysed in a SDT-2960 thermobalance (TA-Instruments, USA). The instrument was preliminarily calibrated with two weight standard references and with standard calcium oxalate monohydrate. All mass loss percentages were determined using Universal Analysis-2000 data analysis software.

Differential scanning calorimetry (DSC): The DSC curves were obtained using thermal analysis system model DSC-Q200 (TA-Instruments, USA) and were recorded under an air flow of $50 \mathrm{~mL} \mathrm{~min}{ }^{-1}$, heating rate of $5.0^{\circ} \mathrm{C} \mathrm{min}{ }^{-1}$ and samples weighing about $2.0 \mathrm{mg}$ dispersed in $10 \mu \mathrm{L}$ of distilled water. The instrument was calibrated using Indium $99.99 \%$ purity, m.p. $=156.6{ }^{\circ} \mathrm{C}, \Delta \mathrm{H}=$ $28.56 \mathrm{~J} \mathrm{~g}^{-1}$. A 4:1 (water:starch, w/w) mixture was prepared and maintained for 60 minutes in order to equilibrate the moisture content. The aluminium crucibles were sealed in order to study the gelatinisation process.

Rapid Viscoamylographic Analysis (RVA): The pasting properties of the samples were determined using RVA-4 (Newport Scientific, Australia). A suspension of 3 $\mathrm{g}$ (6\% moisture) cassava bagasse and starch in $25 \mathrm{~g}$ of distilled water underwent a controlled heating and cooling cycle under constant shear (160 rpm), where it was held at $50{ }^{\circ} \mathrm{C}$ for two min, heated from 50 to $95^{\circ} \mathrm{C}$ at $6{ }^{\circ} \mathrm{C} \mathrm{min}{ }^{-1}$, and held at $95{ }^{\circ} \mathrm{C}$ for $5 \mathrm{~min}$, cooled to $50{ }^{\circ} \mathrm{C}$ at $6{ }^{\circ} \mathrm{C} \mathrm{min}{ }^{-1}$ and held at $50{ }^{\circ} \mathrm{C}$ for $2 \mathrm{~min}$ (Sun et al., 2013; Beninca et al., 2012).

Non-contact Atomic Force Microscopy (NC-AFM): The micro-images of each sample were observed with high resolution by an Atomic Force Microscope model SPM-9600 (Shimadzu, Japan), using the non-contact method (Beninca $\boldsymbol{e}$ al., 2012; Juszczak et al., 2008). The technique allowed us to observe the surface of the studied cassava bagasse, and it was possible to identify starch granules and natural fibres.

\section{RESULTS AND DISCUSSION}

In the laboratory, sample A was dried carefully in an oven with forced air circulation at $45^{\circ} \mathrm{C}$ for 24 hours, ground and sieved at 20,150 and 270 mesh, and kept in a desiccator over anhydrous calcium chloride until constant mass. The cassava bagasse is hygroscopic: even in a desiccator it retains moisture content, and the values can be observed from the physicochemical and thermogravimetric determinations (IAL, 2008; Wendlandt, 1986).

The main results of the physicochemical analyses of the studied cassava bagasse samples are shown in Table 1.

Table 1 Physicochemical analysis of the industrial cassava bagasse (A) and (b) at 270 mesh

\begin{tabular}{lcc}
\hline \hline Analysis & Cassava Bagasse (A) & Cassava Bagasse (B) \\
\hline \hline Moisture & $8.70( \pm 0.01) \%^{\mathrm{a}}$ & $5.39( \pm 0.01) \%^{\mathrm{b}}$ \\
\hline Ash & $2.15( \pm 0.09) \%^{\mathrm{a}}$ & $2.04( \pm 0.03) \%^{\mathrm{a}}$ \\
\hline Protein & $1.65( \pm 0.01) \%^{\mathrm{b}}$ & $1.97( \pm 0.14)^{\mathrm{a}}$ \\
\hline Starch & $47.75( \pm 0.21) \%^{\mathrm{a}}$ & $41.31( \pm 0.43) \%^{\mathrm{a}}$ \\
\hline Reducing Sugars & $0.17( \pm 0.01) \%^{\mathrm{b}}$ & $0.43( \pm 0.10) \%^{\mathrm{a}}$ \\
\hline Glucose & $0.02( \pm 0.00) \%^{\mathrm{a}}$ & $0.01( \pm 0.00) \%^{\mathrm{a}}$ \\
\hline pH & $5.35( \pm 0.01)^{\mathrm{a}}$ & $4.03( \pm 0.01)^{\mathrm{b}}$ \\
\hline \hline
\end{tabular}

Averages followed by the same letters do not differ statistically by Tukey test $(\mathrm{p}<0.05)$.
TG-DTA results (Figure 1) were obtained with the samples in granulometry of 270 mesh and they showed similarity in the steps and temperatures of decomposition, as well as in the endothermic or exothermic peaks.
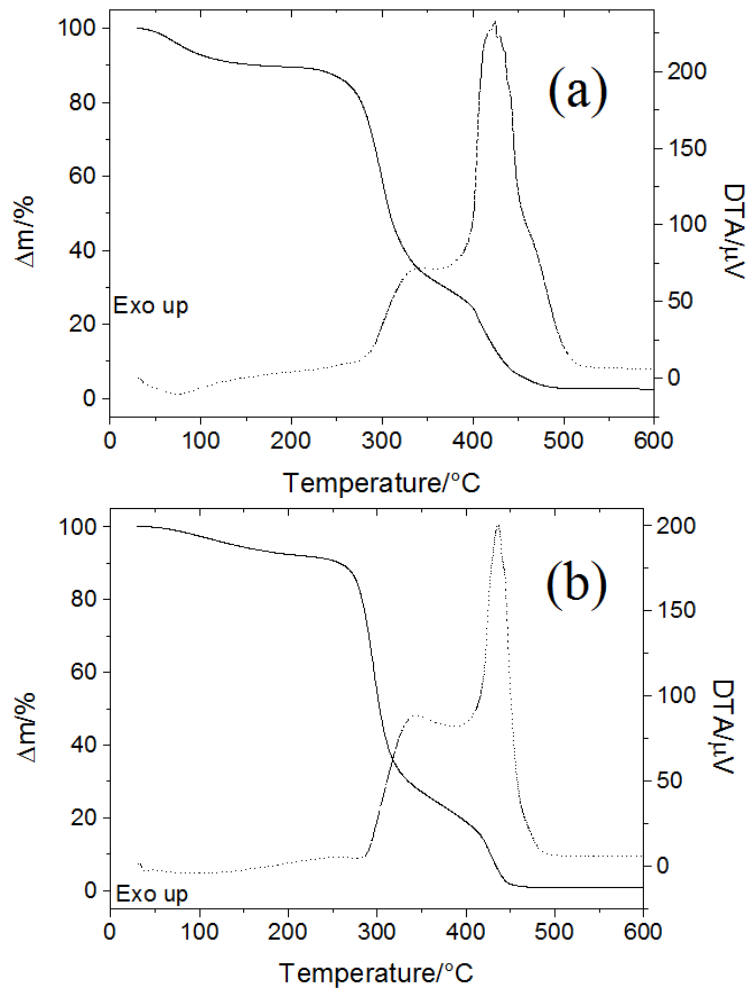

Figure 1 TG-DTA curves of (A) and (B) samples

The TG curves showed mass losses in three stages; the first was due to dehydration, with a corresponding endothermic peak in the DTA curve. When anhydrous, each sample was stable up to 219 and $235^{\circ} \mathrm{C}$, samples A and B respectively. The second and third mass losses are attributed to the decomposition of organic matter with corresponding exothermic peaks (DTA) and with the formation of final residues (ash) that were 2.18 and $1.89 \%$ (w/w), respectively. All the obtained results are shown in Table 2 and the moisture and ash contents are in agreement with those obtained by the physicochemical methods.

Table 2 TG-DTA results of (A) and (B) samples at 270 mesh

\begin{tabular}{|c|c|c|c|c|}
\hline \multirow{2}{*}{ Samples } & \multicolumn{2}{|c|}{ TG Results } & \multicolumn{2}{|c|}{ DTA Results } \\
\hline & Step & $\Delta \mathrm{m} / \%$ & $\Delta \mathrm{T} /{ }^{\circ} \mathrm{C}$ & $\mathbf{T}_{\mathbf{p}} /{ }^{\circ} \mathbf{C}$ \\
\hline \multirow{3}{*}{$\mathbf{A}$} & $1^{\mathrm{st}}$ & 9,15 & $30-132$ & 87 (endo) \\
\hline & $2^{\text {nd }}$ & 56,45 & $219-342$ & 331 (shoulder-exo) \\
\hline & $3^{\text {rd }}$ & 31,62 & $342-496$ & $423(\mathrm{exo})$ \\
\hline \multirow{2}{*}{ B } & $1^{\text {st }}$ & 5,32 & $30-145$ & 95 (endo) \\
\hline & $3^{\text {rd }}$ & 25,47 & $352-458$ & 437(exo) \\
\hline
\end{tabular}

${ }^{(*)} \Delta \mathrm{m}$ mass loss $(\%), \Delta \mathrm{T}$ temperature range, $\mathrm{T}_{\mathrm{p}}$ peak temperature 
The DSC curve of each sample was carried out in triplicate, with $2.0 \mathrm{mg}$ of milled cassava starch and $10 \mu \mathrm{L}$ of distilled water, in aluminum crucible that was sealed and maintained for 60 minutes in order to equilibrate the moisture content The granulometry of each sample was 20, 150 and 270 mesh, respectively, and the curves are shown in Figure 2.

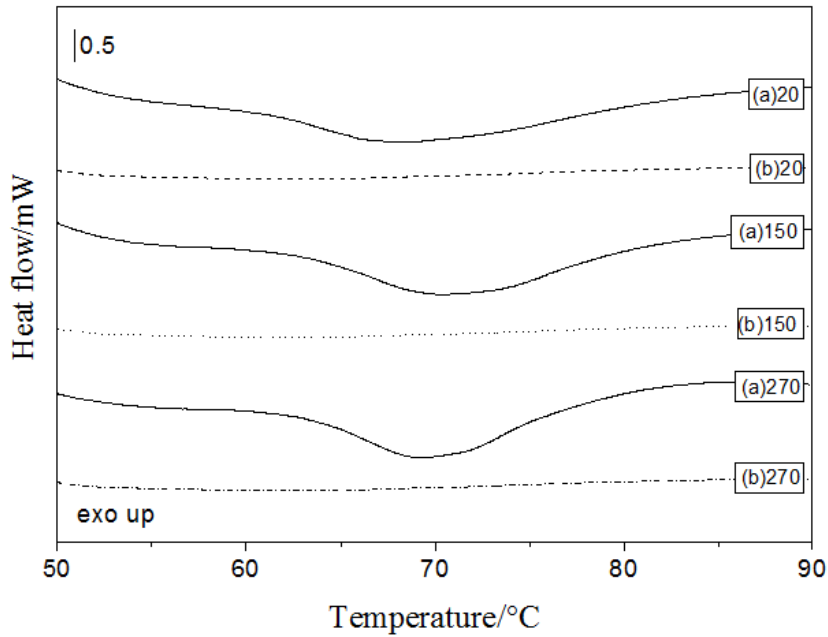

Figure 2 DSC curves: (a) sample 20 mesh, (a) sample at 150 mesh, (a) sample at 270 mesh, (b) sample at 20 mesh, (b) sample at 150 mesh, (b) sample at 270 mesh
The "onset" temperature $\left(\mathrm{T}_{\mathrm{o}}\right)$, "peak" temperature $\left(\mathrm{T}_{\mathrm{p}}\right)$, "endset" or "conclusion" temperature $\left(\mathrm{T}_{\mathrm{c}}\right)$, as well as gelatinisation enthalpy $(\Delta \mathrm{H}$ gel) were calculated, and the results are shown in Table 3 . The gelatinisation enthalpy for sample A was inversely proportional to the granulometry, due to larger contact surface.

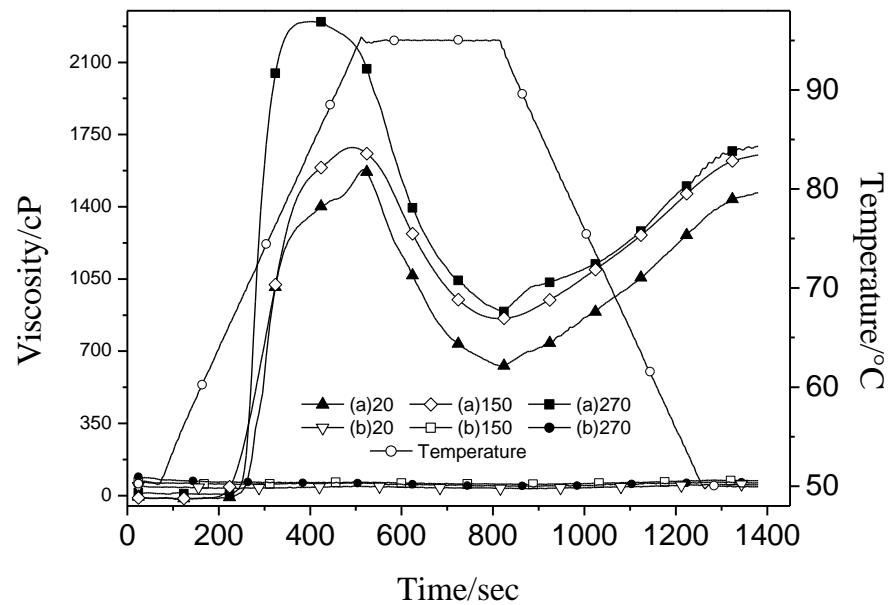

Figure 3 RVA curves of: (a) sample 20 mesh, (a) sample at 150 mesh, (a) sample at 270 mesh, (b) sample at 20 mesh, (b) sample at 150 mesh, (b) sample at 270 mesh. $(1 \mathrm{cP}=1 \mathrm{mPa} \mathrm{s})$

Table 3 DSC results of (A) samples in different granulometries 20, 150 and 270 mesh

\begin{tabular}{ccccc}
\hline \hline Samples & $\mathrm{T}_{\mathrm{o}} /{ }^{\circ} \mathrm{C}$ & $\mathrm{T}_{\mathrm{p}} /{ }^{\circ} \mathrm{C}$ & $\mathrm{T}_{\mathrm{c}} /{ }^{\circ} \mathrm{C}$ & $\Delta \mathrm{H}_{\mathrm{gel}} / \mathrm{J} \mathrm{g}$ \\
\hline \hline (A) $20 \mathrm{mesh}$ & $59.23 \pm 0.96^{\mathrm{b}}$ & $68.57 \pm 0.47^{\mathrm{b}}$ & $84.13 \pm 0.40^{\mathrm{a}}$ & $5.63 \pm 0.51^{\mathrm{b}}$ \\
\hline (A) $150 \mathrm{mesh}$ & $61.30 \pm 0.50^{\mathrm{a}}$ & $70.43 \pm 0.40^{\mathrm{a}}$ & $82.07 \pm 0.38^{\mathrm{b}}$ & $7.70 \pm 0.44^{\mathrm{a}}$ \\
\hline (A) $270 \mathrm{mesh}$ & $61.73 \pm 0.31^{\mathrm{a}}$ & $69.63 \pm 0.42^{\mathrm{ab}}$ & $79.30 \pm 0.20^{\mathrm{c}}$ & $8.77 \pm 0.31^{\mathrm{a}}$ \\
\hline \hline
\end{tabular}

(*) $\mathrm{T}_{\mathrm{o}}$ "onset" initial temperature, Tp peak temperature, $\mathrm{T}_{\mathrm{c}}$ "endset" or conclusion temperature, $\Delta \mathrm{H}_{\mathrm{ge}} \mathrm{l}$ gelatinization enthalpy,

(**) Averages followed by the same letters in the same column do not differ statistically by Tukey test $(\mathrm{p}<0.05)$.

Only sample A showed gelatinisation process in any granulometry and for sample B, although containing starch, this phenomenon was not observed, which was attributed to the industrial drying process. As for the gelatinisation enthalpy, the viscosity peak and the final viscosity for sample A were inversely proportional to the granulometry. Sample B did not show these pasting properties and the RVA curves were superposed. All the RVA curves are shown in Figure 3 and the results in Table 4

Table 4 RVA results of (A) samples in different granulometries 20, 150 and 270 mesh

\begin{tabular}{cccccc}
\hline \hline Samples & $\begin{array}{c}\text { Pasting } \\
\text { temperature/ }{ }^{\circ} \mathbf{C}\end{array}$ & Viscosity peak/cP & Peak time/sec & Setback/cP & Break/cP \\
\hline \hline (A) 20 mesh & $71.7 \pm 0.72^{\mathrm{a}}$ & $1578.7 \pm 7.77^{\mathrm{c}}$ & $515.7 \pm 5.51^{\mathrm{a}}$ & $839.3 \pm 3.79^{\mathrm{a}}$ \\
\hline (A) $\mathbf{1 5 0}$ mesh & $67.5 \pm 0.22^{\mathrm{c}}$ & $1684.3 \pm 3.06^{\mathrm{b}}$ & $491.3 \pm 4.04^{\mathrm{b}}$ & $792.3 \pm 2.52^{\mathrm{c}}$ \\
\hline (A) $\mathbf{2 7 0}$ mesh & $69.6 \pm 0.25^{\mathrm{b}}$ & $2292.3 \pm 4.93^{\mathrm{a}}$ & $404.3 \pm 4.04^{\mathrm{c}}$ & $801.7 \pm 4.04^{\mathrm{b}}$ \\
\hline \hline
\end{tabular}

${ }^{*}$ cP "centipoises", sec "seconds", (**) Averages followed by the same letters in the same column do not differ statistically by Tukey test (p<0.05).

In Figure 4 the micro-images of each sample obtained by atomic force microscopy by the non-contact method are shown. From sample A, the height difference was of $2.95 \mu \mathrm{m}$ and it was possible to observe some granules whose

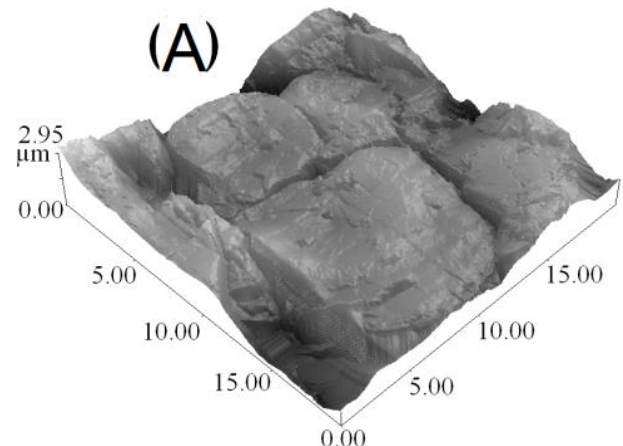

average diameter was $8.73 \pm 2.05 \mu \mathrm{m}$. The average roughness was $332.86 \pm 2.83$ $\mu \mathrm{m}$

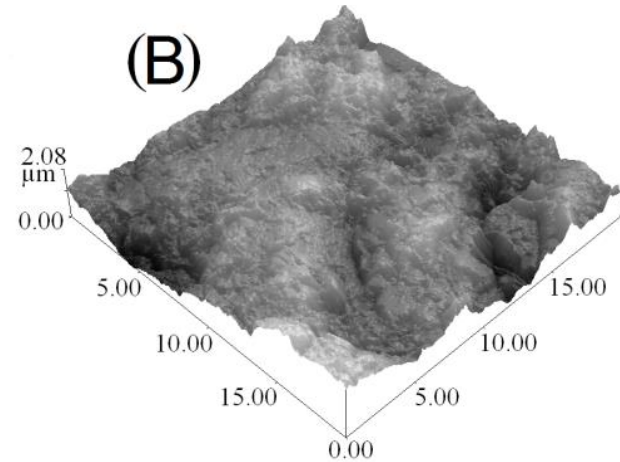

Figure 4 NC-AFM images of: (A) sample at 270 mesh, height difference $2.95 \mu \mathrm{m}$; (B) sample at 270 mesh, height difference $2.08 \mu \mathrm{m}$ 
From sample B, the height difference was of $2.08 \mu \mathrm{m}$; the starch granules could not be observed clearly due to the great quantity of cellulose fibres, and thus the average diameter could not be measured. The average roughness obtained was $254.32 \pm 1.30 \mu \mathrm{m}$.

\section{CONCLUSION}

TG curves of cassava bagasse showed similar behaviour; the samples showed three mass losses, the first due to dehydration, followed by stability and subsequently, decomposition (oxidation of starch and cellulose) in two consecutive steps. Each DTA event occurred with one endotherm (dehydration) followed by stability and two exothermic reactions, in agreement with the TG curves. Sample A, which was dried in a laboratory at $50{ }^{\circ} \mathrm{C}$ showed gelatinisation process, viscosity and pasting properties in any granulometry. Sample B did not show the gelatinisation process or pasting properties due to the industrial drying procedure that caused starch gelatinisation as well as a slight darkening of the bagasse.

Acknowledgments: The financial resources for this study were supported by CAPES, CNPq and Fundação Araucária (Brazil), for which the authors are grateful. C-LABMU/PROPESP (UEPG) by AFM and TG-DTA analysis performed.

\section{REFERENCES}

ABDUL-KHALIL, H.P.S., BHAT, A.H., YUSRA, A.F.I. 2012. Green composites from sustainable cellulose nanofibrils: A review. Carbohydr Polym, 87, 963-979. http://dx.doi.org/10.1016/j.carbpol.2011.08.078

ALBERTON, C., COLMAN, T.A.D., SOUZA, J.A., OLIVEIRA, C.S., ANDRADE, M.M.P., SCHNITZLER, E. 2014. Thermal analysis, rheology, x-ray diffractometry and atomic force microscopy in the evaluation of binary mixtures of "starch-hydrocolloids". J Microbiol Biotech Food Sci., 3(4), 305-309.

AOAC. 2010. Official Methods of Analysis of AOAC International. In: Association of Official Analytical Chemists $18^{\text {th }}$ ed.

BENINCA, C., COLMAN, T.A.D., LACERDA, L.G., FILHO, M.A.S.C. DEMIATE, I.M., BANNACH, G., SCHNITZLER, E. 2013. Thermal, rheological and structural behaviors of natural and modified cassava starch granules, with sodium hypochlorite solutions. J Therm Anal Calorim, 111(3), 2217-2222. http://dx.doi.org/10.1007/s10973-012-2592-z

CARTA, F.S., SOCCOL, C.R., RAMOS L.P., FONTANA, J.D. 1999. Production of fumaric acid by fermentation of enzymatic hydrolysates derived from cassava bagasse. Bioresour Technol, 68, 23-28. http://dx.doi.org/10.1016/S0960-8524(98)00074-1

CEREDA, M. P. 2001. Propriedades Gerais do Amido. FUND. CARGILL 221 p ISBN 85-88764-25-3.

COLMAN, T.A.D., BICUDO, S.C.W., LACERDA, L.G., CARVALHO-FILHO, M.A.S., DEMIATE, I.M., BANNACH, G., SCHNITZLER, E. 2012 Characterization of wheat starch by thermoanalytical, rheological and atomic force microscopy techniques. Braz. J. Therm. Anal, 1, 62-65.

CORDOBA, L.P., RIBEIRO, L.S., COLMAN, T.A.D., OLIVEIRA, C.S ANDRADE, M.M.P., COSTA, F.J.O.G., SCHNITZLER, E. 2013. Effect of hydrochloric acid in different concentrations and temperatures up to some properties of organic cassava starch. Braz. J. Therm. Anal., 2(1), $6-11$.

COSTA, F.J.O.G., ALMEIDA, R.R., LACERDA, L.G., CARVALHO-FILHO M.A.S., BANNACH, G., SCHNITZLER E. 2011. Thermoanalytical study of native cassava starch and treated with hydrogen peroxide. Aliment Nutr, 22(1), 7 15.

FUKUOKA, M., OHTA, K.I., WATANABE, H. 2002. Determination of the terminal extent of starch gelatinization in a limited water system by DSC. $J$ Food Eng, 53, 39-42. http://dx.doi.org/10.1016/S0260-8774(01)00137-6

IAL. 2008. Métodos físicos e químicos para análise de alimentos. In: IAL. Normas Analíticas. (Instituto Adolfo Lutz, São Paulo), $5^{\text {th }}$ ed.

JUSZCZAK, L., FORTUNA, T., KROK, F. 2008. Non-contact atomic force microscopy of starch granules surface. Part I. Potato and tapioca starches. Starch/Staerke, 55, 1-7. http://dx.doi.org/10.1002/star.200390012

KISELEVA, V. I., KRIVANDIN, A.V., FORNAL, J., BŁASZCZAK, W. JELIŃSKI, T., YURYEV, V. P. 2005.. Annealing of normal and mutant wheat starches. LM, SEM, DSC, and SAXS studies. Carbohydr Res, 340(1), 75-83 http://dx.doi.org/10.1016/j.carres.2004.10.012

LACERDA, L.G., ALMEIDA, R.R., DEMIATE, I.M., CARVALHO-FILHO, M.A.S., VASCONCELOS, E.C., WOICIECHOWSKI, A.L., BANNACH, G., SCHNITZLER, E., SOCCOL, C.R. 2009. Thermoanalytical and Starch Content Evaluation of Cassava Bagasse as Agro-Industrial Residue. Braz Arch Biol Technol, 52, 143-150.

LACERDA, L.G., AZEVEDO, J.A.M., CARVALHO-FILHO, M.A.S., DEMIATE, I.M., SCHNITZLER, E., VANDENBERGHE, L.P.S., SOCCOL C.R. 2008b. Thermal characterization of Partially Hydrolyzed Cassava (Manihot esculenta) Starch Granules. Braz Arch Biol Technol, 51(6), 1209-1216.
LACERDA, L.G., CARVALHO-FILHO, M.A.S., DEMIATE, I.M., BANNACH, G., IONASHIRO, M., SCHNITZLER E. 2008a. Thermal behaviour of corn starch granules under action of fungal alpha-amylase. $J$ Therm Anal Calorim, 93(2), 445-449. http://dx.doi.org/10.1007/s10973-006-8273-z

LEIVAS, C.L., COSTA, F.J.O.G., ALMEIDA, R.R., FREITAS, R.J.S., STERTZ, S.C., SCHNITZLER, E. 2013. Structural characteristics, physico-chemical, thermal and pasting properties of potato (Solanum tuberosum, L.) flour: study of different cultivars and granulometries. J Therm Anal Calorim, 111(3), 22112216. http://dx.doi.org/10.1007/s10973-012-2395-2

MATSUGUMA, L.S., LACERDA, L.G., SCHNITZLER, E., CARVALHOFILHO, M.A.S., FRANCO, C.M.L., DEMIATE, I.M. 2009. Characterization of Native and Oxidized Starches of Two Varieties of Peruvian Carrot (Arracacia xanthorrhiza, B.) From Two Production Areas of Paraná State, Brazil. Braz Arch Biol Technol, v.52(3), 701-713.

MATSUI, K.N., LAROTONDA, F.D.S., PIRES, A.T.N., LAURINDO,J.B. 2003 Moisture isotherms of cassava bagasse composites impregnated with cassava starch acetate solutions. Aliment Nutr, v.14(2), 137-140.

PANDEY, A., SOCCOL, C.R., NIGAM, P., SOCCOL, V.T., VANDENBERGHE, L.P.S., MOHAN, R. 2000. Biotechnological potential of agro-industrial residues II: cassava bagasse. Bioresour Technol, 74(1), 81-87. http://dx.doi.org/10.1016/S0960-8524(99)00143-1

PANDEY, A.; SOCCOL, C.R. 2000a. Economic utilization of crop residues for value addition: A futuristic approach. $J$ Sci Ind Res, 59, 12-22.

PANDEY, A.; SOCCOL, C.R.; MITCHELL, D. 2000b. New developments in solid state fermentation: I-bioprocesses and products Process Biochem (Amsterdam, Neth), 35(10), 1153-1169. http://dx.doi.org/10.1016/S00329592(00)00152-7

PONGSAWATMANIT, R.; TEMSIRIPONG, T.; SUWONSICHON, T. 2007 Thermal and rheological properties of tapioca starch and xyloglucan mixtures in the presence of sucrose. Food Res Int, 40(2), 239-248. http://dx.doi.org/10.1016/j.foodres.2006.10.013

RICHARDSON, S., GORTON, L. 2003. Characterisation of the substituent distribution in starch and cellulose derivatives. Anal Chim Acta, 497, 27-65. http://dx.doi.org/10.1016/j.aca.2003.08.005

SIVARAMAKRISHNAN, S.,GANGADHARAN, D., NAMPOOTHIRI, K.M., SOCCOL, C.R., PANDEY, A. 2007.Alpha amylase production by Aspergillus oryzae employing solid-state fermentation. J Sci Ind Res, 66(8), 621-626.

SUN Q., SI, F., XIONG, L., CHU, L. 2013. Effect of dry heating with ionic gums on physicochemical properties of starch. Food Chem, 136(3-4),1421-1425 http://dx.doi.org/10.1016/i.foodchem.2012.09.061

TEIXEIRA, E.M., RÓZ, A.L., CARVALHO, A.J.F., CURVELO, A.A.S. 2009 Preparation and characterisation of thermoplastic starches from cassava starch, cassava root and cassava bagasse. Macromol Symp, 229, 266-275. http://dx.doi.org/10.1002/masy.200551133

VILAPLANA, F.; HASJIM, J.; GILBERT, R. G. 2012. Amylose content in starches: Toward optimal definition and validating experimental methods. Carbohydr Polym, 88(1), 103-111. http://dx.doi.org/10.1016/j.carbpol.2011.11.072

WENDLANDT, W.W. 1986. Thermal Analysis. Wiley \& Sons, New York, $3^{\text {rd }}$ ed. 832p, IBSN-10 0471884774

ZHANG, X., TONG, Q., ZHU W., REN, F. 2013. Pasting, rheological properties and gelatinization kinetics of tapioca starch with sucrose or glucose. J Food Eng, 114(2), 255-261. http://dx.doi.org/10.1016/j.jfoodeng.2012.08.002 